\title{
Death, Decay and Delight in Cyprian of Carthage
}

\author{
Edwina Murphy \\ Morling College, Australian College of Theology and University of Divinity, \\ Macquarie Park Nsw 2113, Australia \\ edwinam@morling.edu.au
}

\begin{abstract}
A martyr's suffering and death is glorious, says Cyprian of Carthage. No surprises there. But what about the ageing, suffering and death common to humanity? Old age is naturally associated with physical decline in people, just as the ageing world is diminishing in vigour. Elders must be respected, however, and signs of age should be valued, not erased. Furthermore, just as the end of the world is a matter of hope for the Christian, so is the end of one's life - the gateway to everlasting joy. As Cyprian emphasises in De mortalitate, even the suffering caused by the plague is to be embraced rather than spurned; afflictions are cause for rejoicing as by them Christians are proved, strengthened and ultimately crowned. Cyprian's characteristic distinction between the physical and the spiritual, the temporal and the eternal, is prominent as he encourages his flock to persevere in the midst of turbulent times.
\end{abstract}

\section{Keywords}

Ageing - plague - De mortalitate - biblical interpretation - patristic exegesis

Cyprian was bishop of Carthage for a decade in the middle of the third century, a decade marked by persecution, schism and plague. He himself died as a martyr in 258. In the midst of such turmoil, what was Cyprian's perspective on ageing? What honour and responsibilities do older people have? And how

1 For a biography of Cyprian, see Michael M. Sage, Cyprian, Philadelphia, PA, 1975. For the impact of persecution and schism on Cyprian's ecclesiology, see J. Patout Burns, Cyprian the Bishop, London, 2002. 
should infirmity, illness and death - whether due to age or other causes ultimately be viewed?

Old age naturally brings with it a sense of decline. It is because the world is ageing, a commonplace of late antique thought, ${ }^{2}$ that it is no longer as fertile and productive as it once was. Cyprian mostly uses this trope apologetically since whatever is born dies, ${ }^{3}$ Christians cannot be held responsible for the fact that "everything is diminished as the world grows old." ${ }^{4}$ But Cyprian also diverges from his contemporaries: in contrast to Stoic and Lucretian views, ${ }^{5}$ he claims that "the world is tottering and collapsing and bearing witness to its ruin, not now through age, but through the end of things." ${ }^{6}$ And this end is not viewed pessimistically, as a falling away from a once-golden age, but "is laden with implications of hope." Cyprian eagerly awaits the inauguration of a new age, contrasting Christian vibrancy with the deterioration of the world: "The strength of hope and firmness of faith flourishes among us, and in the midst of the very ruins of a collapsing world our mind is lifted up, our courage unshaken, our patience never unhappy, and our soul always secure in God." Juxtaposing the present and the future, with their respective trials and rewards, is a common technique of Cyprian's, as will become increasingly evident throughout the paper. ${ }^{9}$

2 Although other themes are also present: the Aeternitas of Roma perpetua or aeterna, for example. Henri-Irénée Marrou, "La fin du monde antique vue par les contemporains," in Christiana tempora, Rome, 1978 , p. 80.

3 "omnia orta occidant." Demetr. 3 (CCSL 3A:37). Cyprian's phrase echoes Sallust, who declared: "omnia orta intereunt." Rep. 1.5 (LCL 522:488). Sallust, however, has a different solution to a different problem: Caesar must establish harmony in Rome to avoid its fall. Santo Mazzarino, The End of the Ancient World, London, 1966, p. 27.

4 "minuantur singula mundo senescente." Demetr. 4 (CCSL 3A:37). Translations of the treaties are modified from ANF. Cyprian also refers to the decline of the world in Unit. eccl. 16 (ccsL 3:261) and Epp. 58.2.1, 67.7 (CCSL $3 \mathrm{C}: 321,458)$. The imminent end of the world is declared in Demetr. 23 (CCSL 3A:48-49). For Cyprian in his context, see Allen Brent, Cyprian and Roman Carthage, Cambridge, 2010, pp. 96-116.

5 Stoics expected cosmic conflagration and rebirth; Lucretius believed that the universe will end simply because nothing is eternal. Natale Spineto, "L'escatologia nel mondo classico," ASE, 16 (1999), p. 19.

6 "Mundus ecce nutat et labitur et ruinam sui non iam senectute rerum sed fine testatur." Mort. 25 (CCSL $3 \mathrm{~A}: 30)$. Italics mine. Cyprian uses this as a reason to welcome death rather than fear it, and to rejoice in the escape from imminent disaster.

7 Luigi Castagna, "Vecchiaia e morte del mondo in Lucrezio, Seneca e San Cipriano," AevAnt, 13 (2000), p. 252 n. 23.

8 "Viget aput nos spei robur et firmitas fidei et inter ipsas saeculo labentis ruinas erecta mens est et inmobilis uirtus et numquam non laeta patientia et de Deo suo semper anima secura." Demetr. 20 (CCSL 3A:46-47).

9 For more on this theme in Cyprian, see Edwina Murphy, The Bishop and the Apostle: Cyprian's Pastoral Exegesis of Paul, Berlin, 2018, pp. 33-35. 
While the world might be in decline and fading, each of us comes to our own personal end. Old age sees the weakening of strength, the dimming of sight and hearing, a slowing of pace. The powers of youth cannot be expected to last forever. ${ }^{10}$ Exceptions to this rule only occur by God's intervention Sarah, long barren, conceives in her old age. ${ }^{11}$ But the declining physical abilities of older people are no reason to treat them with disrespect. A case in point: Bishop Rogatianus is having problems with an unruly deacon who does not, apparently, show appropriate respect for his age. Cyprian and his fellow bishops assure Rogatianus that such arrogance on the deacon's behalf is not accepted by God, as seen in how he responded when the prophet Samuel was so treated:

Furthermore, when, in the Book of Kings, the Jewish people held Samuel in scorn because of his age - as you now have been - the Lord cried out in anger and said: 'They have not despised you, they have despised me.'12 And as vengeance for this, He raised up Saul to be their King to beset them with grave hardships and to tread underfoot and oppress this arrogant nation with all kinds of insult and punishment. In this way through divine retribution the priest was avenged for the scorn in which this arrogant nation had held him. ${ }^{13}$

This is followed by various other testimonies regarding "the priest's authority and power."14 Towards the end of the letter, however, Cyprian returns to the theme of the bishop's age, rewriting 1 Tim 4:12: "The Apostle Paul, writing to Timothy, said: 'Let no man despise you for your youth. ${ }^{15}$ Your colleagues have,

10 Demetr. 4 (CCsL $3 \mathrm{~A}: 37)$.

11 Test. $1.20(\mathrm{CCSL} 3: 20)$.

121 Sam 8:7.

13 "In libro quoque Regnorum cum Samuel sacerdos a Iudaeorum populo ob senectutem, sicut tu modo, contemneretur, exclamauit iratus dominus et dixit: 'non te spreuerunt, sed me spreuerunt.' Et ut hoc ulcisceretur, excitauit eis Saul regem, qui eos iniuriis grauibus adfligeret et per omnes contumelias et poenas superbum populum calcaret et premeret, ut contemptus sacerdos de superbo populo ultione diuina uindicaretur." Ep. 3.1.2 (CCSL 3A:11). Translations of Cyprian's letters are from Graeme W. Clarke, The Letters of St. Cyprian of Carthage, 4 vols., New York, 1984-1989. For Cyprian's depiction of Saul, see Edwina Murphy, "Imitating the Devil: Cyprian on Jealousy and Envy," Scr, 14 (2018), pp. 86-88.

14 "sacerdotalis auctoritas et potestas." Ep. 3.2.1 (CCSL 3 B:12). As Simone Deléani notes, two exempla from the Old Testament on the honouring of priests (Aaron and Samuel) are matched with two New Testament exempla (Paul and Christ). Simone Deléani, Saint Cyprian: Lettres 1-20, Paris, 2007, pp. 69-70.

As Clarke says, this is a "re-writing of the Biblical text for dramatic effectiveness." Clarke, Letters, vol. 1, p. 169. Cyprian only does this three times altogether - the other two are John 5:14b in Ep. 13.2.2 (CCSL 3B:72-73) and Matt 25:36 in Ep. 62.3.1 (CCSL 3 C:387). See Michael 
accordingly, all the more reason for saying to you: 'Let no man despise you for your age."16 If the deacon persists in his insolent behaviour, Rogatianus should not hesitate to use his episcopal powers to depose or excommunicate him.

Not only elderly bishops, but older people in general deserve particular respect. In the testimony, "We must not rashly accuse an older person,"17 Cyprian's supporting text is "Do not receive an accusation against an older person."18 Cyprian's Old Latin text most likely follows the Greek in using the same word, "elder," in both 1 Tim. 5:1 and 1 Tim. 5:17-20, ${ }^{19}$ whereas the later Vulgate text distinguishes between older men in general and elders as leaders (presbyters) in particular. ${ }^{20}$ As the technical term presbyter does not appear in Cyprian's text, he simply applies the verse to older people generally. ${ }^{21}$ Conversely, a text from Leviticus that directs people to stand in the presence of an older person is transformed into a testimony that "We should stand when a bishop or presbyter comes." 22

Along with the privileges of old age come responsibilities: the older must teach the younger, as Cyprian advises in De habitu virginum. ${ }^{23}$ And furthermore, senior widows should not seek to hide a sign of their age, their grey hairs. This is not only an attempt to overturn Jesus' words that "You cannot make one hair white or black," ${ }^{24}$ but also a refusal to be found in his likeness, since it is written in the Book of Revelation, "His head and his hair were white like wool

Andrew Fahey, Cyprian and the Bible: A Study in Third-Century Exegesis, Tübingen, 1971, pp. 51-52. In each case, Cyprian cites the original version before rewriting it.

"Nam si apostolus Paulus ad Timotheum scribens dixit: 'iuuentutem tuam nemo despiciat,' quanto magis tibi a collegis tuis dicendum est: 'senectutem tuam nemo despiciat?" Ep. 3·3·3 (CCSL 3B:15). This also creates a parallel between the apostle Paul and the episcopal colleagues of Rogatianus, successors of the apostles. Deléani, Lettres, p. 88.

17 Fahey, Cyprian, p. 509. "Maiorem natu non temere accusandum"' Test. 3.76 (CCSL 3:161).

18 "Aduersus maiorem natu accusationem ne receperis." Test. 3.76 (CcsL 3:161). The Vulgate reads: "Aduersus presbyterum accusationem noli recipere."

19 Although Cyprian never cites 1 Tim. 5:1, so it is not possible to be certain.

$20 \quad$ Where 1 Tim. 5:1 reads: "Seniorem ne increpaveris."

21 For further discussion, see Edwina Murphy, "Widows, Welfare and the Wayward: 1 Timothy 5 in Cyprian's Ad Quirinum," StPatr, 94 (2017), pp. 72-73.

22 "Surgendum, cum episcopus aut presbyter ueniat." The quotation from Lev 19:32 reads: " $A$ facie senioris exurges et honorabis personam presbyteri." Test. 3.85 (CCSL 3:164).

23 "Prouectae annis, iunioribus facite magisterium." Hab. virg. 24 (CCsL 3F:319). Dated to 249 by Geoffrey D. Dunn, "Infected Sheep and Diseased Cattle, or the Pure and Holy Flock: Cyprian's Pastoral Care of Virgins," JECs, 11 (2003), p. 5 .

Matt 5:36. "Non potes facere capillum unum album aut nigrum." 
or snow." ${ }^{25}$ This is a rather particular instance of the imitation of Christ so often found in Cyprian. ${ }^{26}$

While age is to be respected, there is also a spiritual equality within the church. In the letter Cyprian and his fellow bishops send to Fidus on infant baptism, it is declared that everybody, no matter how old, shares equally in "the divine bounty." 27 When Elisha stretched himself out over the widow's son (here, an infant), ${ }^{28}$ it is not possible that his hands and feet could have aligned with the child's. This part of the account is intended to illustrate the equality of all in God's sight: "The Holy Spirit is not measured out but is conferred equally upon all through the bounty and loving-kindness of the Father. For just as God draws no distinction between persons, ${ }^{29}$ so neither does He between ages, but He shows Himself a Father equally to all, being evenhanded in the distribution of His heavenly graces." 30 In fact, rather than delaying baptism because of a concern that the foot of an infant is unclean, or waiting for the eighth day in imitation of circumcision, ${ }^{31}$ "if anything could stand in the way of obtaining grace, it would rather be adults, men of mature and more advanced years, who might have their way blocked by their more grievous sins." ${ }^{32}$ But, of course, even the worst of sinners are granted access to God's grace.

Sometimes young people act in such a way that they are deserving of the honour usually reserved for their elders. Cyprian writes two letters regarding young confessors whom he has promoted (in exceptional circumstances, without the usual participation of the congregation), to the position of reader. ${ }^{33}$

25 Rev. 1:14a. "Caput autem eius et capilli erant albi uelut lana aut nix." Hab. uirg. 16 (CCSL $3 \mathrm{~F}: 307)$.

26 For an extensive survey of this theme in Cyprian, see Simone Deléani, Christum sequi: Étude d'un thème dans l'oeuvre de saint Cyprien, Paris, 1979.

27 "diuini muneris." Ep. 64.3.1 (CCsL 3 C:420).

$28 \quad 2$ Sam 4:32-37.

29 Allusion to Rom 2:11, Eph 6:9 and Gal 2:6.

$30 \quad$ "cum spiritus sanctus non de mensura sed de pietate atque indulgentia paterna aequalis omnibus praebeatur. Nam deus ut personam non accipit, sic nec aetatem, cum se omnibus ad caelestis gratiae consecutionem aequalitate librata praebeat patrem." Ep. 64.3.2 (CCSL $\left.{ }_{3} \mathrm{C}: 421\right)$.

$31 \quad$ Ep. 64.4.1-2 (CCsL $3 \mathrm{C}: 421-23)$.

32 "Ceterum si homines inpedire aliquid ad consecutionem gratiae posset, magis adultos et prouectos et maiores natu possent inpedire peccata grauiora." Ep. 64.5.2 (CCSL $3 \mathrm{C}: 423-24)$.

33 For the role of the people in church affairs, see Alexander W.H. Evers, Church, Cities, and People: A Study of the Plebs in the Church and Cities of Roman Africa in Late Antiquity, Leuven, 2010. As Michel Poirier states: “Pour Cyprien, le laïc n'exerce pas dans l'Eglise de droit actif personnel ... Seuls l'évêque [et ceux] désignés par l'évêque, exercent personnellement une charge dans l'Eglise. Mais le peuple en corps, réuni en assemblée, jouit de droits 
Cyprian does bow to custom, however, in refraining from unilaterally appointing them as presbyters - a step too far, even for such qualified candidates:

Our brother Aurelius is a young man with a splendid record; he has already received the Lord's approbation and is dear to God. Tender in years he may be, but he is far advanced in glory for his faith and courage; though junior in terms of natural age, he is senior in honour. ${ }^{34}$

After enumerating his glorious deeds, along with his outstanding humility, ${ }^{35}$ Cyprian declares: "Such a man deserved higher grades of clerical appointment and greater advancement, judged as he should be not on his years but on his deserts." ${ }^{36}$ But for the time being, it will be as a reader that he proclaims the Scriptures, an eminently suitable role for one who has so gloriously confessed. Likewise, Celerinus, following in the footsteps of his glorious forebears by his confession, ${ }^{37}$ has been appointed as a reader, although he, like Aurelius, will receive the stipend of a presbyter: "they will take their seat with us when they have advanced to maturer years ${ }^{38}$ - even though it is impossible to be found in any way deficient in years when you have already brought by honour and glory your life to its perfection."39

So much for the glorious words and exploits of the young. De mortalitate, written to address those whose faith has been shaken by the plague, returns us to the prophetic wisdom of the aged Simeon. It had been revealed to him that

importants." Michel Poirier, “Charité individuelle et action sociale: Réflexion sur l'emploi du mot munus dans le De opere et eleemosynis de saint Cyprien," StPatr, 12 (1975), p. 260.

"Aurelius frater noster inlustris adulescens a domino iam probatus et deo carus est, in annis adhuc nouellus, sed in uirtutis ac fidei laude prouectus, minor in aetatis suae indole, sed maior in honore." Ep. 38.1.2 (CCSL 3B:183).

Ep. 38.1.2-3 (CCSL 3B:183-184). This humility is evidence of his Christ-likeness and consequent suitability for leadership rather than reflecting, as Bobertz would have it, one of the "virtues of clientship ... perhaps to be interpreted as the proper sense of deference to their patron in the service of his interests." C.A. Bobertz, "Patronal Letters of Commendation: Cyprian's Epistulae 38-40," StPatr, 31 (1997), p. 257. For bishops, too, must be humble. See Cyprian's praise of Cornelius as one with "humilitate ingentiae" in Ep. 55.8 (CCSL ${ }_{3} \mathrm{~B}: 265$ ) and Cyprian's defence of his own humility (responding to Puppianus) in Ep.66.3.1-2 (CCsL 3 C:436-37).

36 "Merebatur talis clericae ordinationis ulteriores gradus et incrementa maiora, non de annis suis sed de meritis aestimandus." Ep. 38.2.1 (CCsL 3 B:184).

37 His grandmother, Celerina, and paternal and maternal uncles, Laurentinus and Egnatius, were all martyrs. Ep. 39.3.1 (CCSL 3B:188-89).

38 That is, become presbyters. See Clarke, Letters, vol. 2, p. 194 n. 26.

39 "sessuri nobiscum prouectis et corroboratis annis suis, quamuis in nullo minor possit uideri aetatis indole qui consummauit aetatem gloriae dignitate." Ep. 39.5.2 (CCSL 3 B:192). 
he would not die until he had seen the Messiah, an event he recognised was at hand once he saw Christ enter the temple with his mother. His impending death was not a matter for grieving, however, but rejoicing:

He received the child into his arms, and blessing the Lord, he exclaimed, and said, "Now let your servant depart in peace, according to your word; for my eyes have seen your salvation;" assuredly proving and bearing witness that the servants of God then had peace, then free, then tranquil repose, when, withdrawn from these whirlwinds of the world, we attain the harbour of our home and eternal security, when having accomplished this death we come to immortality."40

Simeon may have already been old, but his response is a model for all those facing death, no matter what their age. This perspective aligns with that expressed in Cyprian's earlier work; similar themes of being freed from the world are present in Ad Donatum. ${ }^{41}$ There too, the body, where God dwells, will not be destroyed but rather re-formed for the better. ${ }^{42}$ And in Ad Quirinum, perhaps a companion piece to $\mathrm{Ad}$ Donatum ${ }^{43}$ there is already a testimony regarding how to think about death: "That no-one should be made sad by death, since in living is labour and peril, in dying peace and the certainty of resurrection." ${ }^{44}$ Included in this testimony are verses from 1 Thessalonians, which Cyprian also uses in De mortalitate. Although the ideas are not novel, the plague forces Cyprian to explicitly address the issue of premature death at a community-wide level in order to reorient his congregation from grief to hope:

Finally, the Apostle Paul reproaches and rebukes and blames any who grieve the departure of their friends. "We do not," he says, "want you to be ignorant, brethren, concerning those who are asleep, so that you do not

$40 \quad$ "accepit in manus puerum et benedicens Deum exclamauit et dixit: 'Nunc dimittis seruum tuum, Domine, secundum uerbum tuum in pace, quoniam uiderunt oculi mei salutare tuum,' probans scilicet adque contestans tunc esse seruis Dei pacem, tunc liberam, tunc tranquillam quietem, quando de istis mundi turbinibus extracti sedis et securitatis aeternae portum petimus, quando expuncta hac morte ad immortalitatem uenimus." Mort. 3 (CCSL 3A:18).

41 See, for example, Don. 14 (CCSL 3A:11-12).

42 "Aboleri non potest nec extingui, potest tantum in melius corpore redeunte formari." Don. 15 (CCSL 3A:15).

43 Mattias Gassman, "Cyprian's Early Career in the Church of Carthage," JEH (2018). doi: 10.1017/Soo22046917002780.

44 "Neminem contristari morte debere, cum sit in uiuendo labor et periculum, in moriendo pax et resurgendi securitas." Test. 3.58 (CCSL 3:143). 
grieve like others who have no hope. For if we believe that Jesus died and rose again, so we believe that God will bring with Jesus those who are asleep in him." ${ }^{45}$ He says that those who grieve the departure of their friends have no hope. ${ }^{46}$

This treatment of grief leads Scourfield to categorise this work an anticonsola$\mathrm{tio}^{47}$ - it is not necessary to console those whose loved ones are already experiencing the joy that the living are still awaiting.

Now, one may be comforted by the thought of being liberated from this world, enjoying the fullness of salvation, ${ }^{48}$ and being reunited with those who have gone before, ${ }^{49}$ but what about the suffering that disease inflicts beforehand? In answer to this question, Cyprian draws on another of the texts from Test. 3.58 . There, he cited ${ }_{1}$ Cor $15: 53-55,{ }^{50}$ and in De mortalitate he alludes to the first of these verses in order to demonstrate that Christians should not be concerned that they suffer physically alongside unbelievers in whatever befalls the world, even if their spiritual situations are very different: "Therefore until this corruptible puts on incorruption, and this mortal receives immortality, ${ }^{51}$ and the Spirit leads us to God the Father, whatever are the disadvantages of the flesh are common to us with the human race." ${ }^{2}$ Christians are not exempt

$45 \quad 1$ Thess 4:13-14.

46 "Inprobat denique apostolus Paulus et obiurgat et culpat, si qui contristentur excessu suorum. 'Nolumus,' inquit, 'ignorare uos, fratres, de dormientibus, ne contristemini sicut et ceteri qui non habent spem. Si enim credimus quia Iesus mortuus est et resurrexit, sic et Deus eos qui dormierunt in Iesu adducet cum eo.' Eos contristari dicit in excessu suorum qui spem non habent." Mort. 21 (CCSL 3A:28).

J.H.D. Scourfield, "The De mortalitate of Cyprian: Consolation and Context," VC, 50 (1996), p. 31 .

48 "This mortality, as it is a plague to Jews and Gentiles, and enemies of Christ, so it is a departure to salvation to God's servants." (Mortalitas ista Iudaeis et gentibus et Christi hostibus pestis est, Dei seruis salutaris excessus est.) Mort. 15 (CCsL 3A:24).

49 Mort. 26 (CCsL 3A:31). Awaiting the Christian are the patriarchs, regarded as "our parents," but so are natural family members. "A great number of our dear ones are waiting for us there, and a dense crowd of parents, brothers and children are longing for us, already assured of their own safety, and still concerned about our salvation. To attain to their presence and their embrace, what happpiness for both them and us!" (Magnus illic nos carorum numeras expectat, parentum, fratrum, filiorum frequens nos et copiosa turba desiderat iam de sua incolumitate secura, adhuc de nostra salute sollicita. Ad horum conspectum et conplexum uenire quanta et illis et nobis in commune laetitia est.) Also there are the apostles, prophets, martyrs, virgins and the merciful.

$50 \quad$ Test. 3.58 (CCSL 3:145-46).

$5^{1} \quad$ Allusion to 1 Cor 15:53.

$5^{2}$ "Itaque donec corruptiuum istud induat incorruptionem, et mortale hoc accipiat inmortali- 
from famine, invasion, drought, shipwreck and, of interest here, "the disease of the eyes, and the attack of fevers, and the feebleness of all the limbs."53

Christians, in fact, will suffer more than others, since they are also battling the devil. ${ }^{54} \mathrm{Job}$, of course, is the classic example of the righteous person patiently enduring suffering 55 - he "was not overcome, but proved." ${ }^{6}$ Tobias, too, is a model - even though he lost his sight, he "by his very bodily affliction increased in praise. ${ }^{57}$ Christians have much to learn from these exemplars. ${ }^{58}$ The key is to recast such sufferings from stumbling blocks to battles, so that faith is not broken, but proved; 59 to be able to say, as Paul did, that he was "not grieved, but benefited by his adversity."60 "This trial," says Cyprian, giving a graphic account of the physical effects of the plague - from vomiting and diarrhoea to loss of hearing and sight and putrefied limbs - "is profitable as a proof of faith. What grandeur of spirit it is to struggle with all the powers of an unshaken mind against so many attacks of devastation and death! ...to rejoice, and to embrace the opportunity." ${ }^{11}$ Faith that is proved will be crowned. This may be through martyrdom, but it may equally be through the suffering and death that is the common lot of humanity.

Presumably Cyprian would have no objection to a healthy mind in a healthy body, but the circumstances facing the members of his congregation force him to deal instead with the inevitability of illness and suffering. Building on ideas present in his earliest writings, he seeks to develop a biblical framework in which these trials can be understood as spiritually beneficial. The virulence of

tatem, et spiritus nos perducat ad Deum patrem, quaecumque sunt carnis incommoda sunt nobis cum humano genere communia." Mort. 8 (CCSL 3A:20-21).

"et oculorum dolor et impetus febrium et omnium ualitudo membrorum." Mort. 8 (CCSL 3A:21).

54 Mort. 9 (CCsL 3 A:21).

55 "Great heroes were listed to illustrate a particular virtue, so a character like Job came to embody patience, and Christ's life and death were set forth as a way to be imitated." Frances M. Young, Biblical Exegesis and the Formation of Christian Culture, Cambridge, 1997, p. 209. Cyprian's use of models unites mimetic and paraenetic readings of Scripture. On this aspect of Chrysostom's work, see Margaret M. Mitchell, The Heavenly Trumpet:John Chrysostom and the Art of Pauline Interpretation, Louisville, KY, 2002, p. 385.

$56 \quad$ "Non uictus est sed probatus." Mort. 10 (CCsL 3A:21).

57 "per ipsam corporis sui ladem creuit ad laudem." Mort. 10 (CCSL 3A:22).

58 Abraham is also mentioned. Mort. $12(\operatorname{ccsL} 3 \mathrm{~A}: 23)$.

59 Mort. 12 (CCSL 3A:23).

$60 \quad$ "ut dum grauius adfligitur uerius probaretur." Mort. 13 (CCSL 3A:23).

61 "Hoc...ad documentum proficit fidei. Contra tot impetus uastitatis et mortis inconcussis animi uirtutibus congredi quanta pectoris magnitudo es...gratulari magis et temporis munus amplecti." Mort. 14 (CCSL 3A:24). 
the plague leads him to focus not on the hope of physical healing, ${ }^{62}$ but on the spiritual gains that result - healing for Cyprian involves regaining the spiritual wholeness which has been lost through $\sin ^{63}$ If one is in a right relationship with God, there is no need to fear the onset of ageing; physical decline is offset by growth in wisdom and respect. Likewise, there is no need to fear departing this world; the next is a haven of peace and security, thanks to the grace of God which is poured out on people of every age. By valuing the eternal over the temporal, no matter what pressure is brought to bear, even the young can attain honour beyond their years. Ultimately, "all the injury inflicted by present troubles is to be despised in the assurance of future blessings." 64

62 Although the attempt should be made. The plague reveals people's hearts: "whether the healthy tend the sick... whether physicians do not desert their pleading patients." (an infirmis seruiat sani... an deprecantes aegros non deserant medici.) Mort. 16 (CCSL 3A:25).

63 As Penniman points out, in De lapsis "the entire Decian persecution is framed in medical terms." John David Penniman, "The Health-Giving Cup': Cyprian's Ep. 63 and the Medicinal Power of Eucharistic Wine," JEcs, 23 (2015), p. 202. See also Barry M. Craig, "Potency Not Preciousness: Cyprian's Cup and a Modern Controversy," Worship, 81 (2007), pp. 290313. Like an experienced doctor, the bishop must bring the cure for the benefit of the patient - no matter how unpleasant at the time. Laps.14 (CCSL 3:228). For further discussion, see Edwina Murphy, "Sin No More: Healing, Wholeness, and the Absent Adulteress in Cyprian's Use of John," REAug, 64 (2018), pp. 9-12.

64 "cum contemnenda sit omnis iniuria malorum praesentium fiducia futurorum bonorum." Mort. 12 (CCsL 3A:23). 